PART II

PERFORMATIVE OF SEX AND GENDER

AND

NEW MEDIA TECHNOLOGY 


\title{
In/Visible: The Political and Sexual Regimes of Databases
}

\author{
Adla Isanović \\ Assistant Professor at The Academy of Fine Arts, Sarajevo, \\ and a PhD student at the Post-graduate School in Nova Gorica, Slovenia \\ (adla_isanovic@yahoo.co.uk)
}

\begin{abstract}
:
This text focuses on the politics and sexual regimes of databases and archives (and art histories) and their relation to human rights, equality and democracy. The main goal is to question, problematize and analyze the cultural and political regimes and strategies deployed in the processes involved in the storage of databases of cultural, artistic, and historical works and events, and, in particular, the regimes of visibility by means of which non-normative sexual experiences and cultural practices are in/excluded from official archives and institutionalized databases, and their consequent influence on the politics of cultural memory and heritage. Setting sexuality and gender as points of investigation, as they are being lived and experienced on the social margins, this text aims to open up for discussion the very foundations of how databases are being conceived and what counts as an archive.
\end{abstract}

Keywords: database, archive, regimes of visibility, art, sexual regimes

\section{Introduction}

It appears that our age is obsessed with rights, both with assigning rights and withdrawing them. The rights to security, liberty and equality and the political and group rights enshrined in the Universal Declaration of Human Rights should guarantee equality and nondiscrimination through social and political instruments, including the regulatory and juridical systems. However, proofs of exceptions and partial implementation are everywhere, from symbolic exclusions to material "deathscapes" whereby individuals and whole populations "are subjected to conditions of life conferring upon them the status of living dead" (Mbembe). ${ }^{1}$

Databases, as a new dominant cultural form (Manovich), ${ }^{2}$ are widely promoted as gender-, class- and race-neutral, even emancipatory. Although 'archives' have been and done different things at different times and under different regimes, from the Greek archeion and the French National Archives to digital databases, archives have always been a site of knowledge production in which political power resided. This is one of the reasons why scholars should move from "archive-as-source" to "archive-as-subject" (Stoler). ${ }^{3}$

Opening a discussion on how databases are conceived and which institutions they serve, I argue in this text that:

- The database as a norm and major neoliberal governmental technology emerges, coexists with, and embodies changing relations within what Michel Foucault has called governmentality.

- The racialization and sexual regimes of databases are involved in the inscription in and exclusion from the register of citizenship (and its rights), while inscribing humans exclusively through hegemonic modernist (hetero) narratives and opposing the human to the figure of a dehumanized racialized Other.

\footnotetext{
$\overline{1}$ Achille Mbembe, "Necropolitics," trans. Libby Meintjes, Public Culture 15/1, (2003), 40.

${ }^{2}$ Lev Manovich, "Database as Symbolic Form," in Database Aesthetics: Art in the Age of Information Overflow, ed. Victoria Vesna (Minneapolis: University of Minnesota Press), 2007, 39-61.

3 Ann Laura Stoler, "Colonial Archives and the Arts of Governance, "Archival Science 2, no.1-2 (2002), 87.
} 
- Art history and institutional archives have a crucial role in "making the visible legible" ${ }^{4}$ and in the "distribution of the sensible ${ }^{\prime \prime}$ in and to the present (and possible future).

- Strategies of resisting Mastery and strategies of redistribution have to include strategies of de-classification and denormalization.

\section{The database as a major global neoliberal governmental technology}

As Foucault has shown, governmentality cannot be reduced to the State, but includes all acts, institutions and rational efforts aimed at systematically shaping, managing and regulating the conduct of human beings. Critical analyses of changing relations in governmentality and life politics thus necessarily need to include three dimensions of government: rationalities (which render reality thinkable in such a way as to make it governable); techniques (the means whereby political reasons are translated into practice); and subjects of government (diverse types of selves, persons, identities and agents which government aims to produce and cultivate through such activities). ${ }^{6}$

Introducing the notions of biopolitics in the 1970s (referring to a way of organizing, managing and regulating the "population" considered as a biological entity, species-being) and biopower (referring to a range of techniques for the subjugation of bodies and control of populations), Foucault articulated why and how the modern state's biopolitical management of life, as the ultimate bourgeois project, have centralized the categories of sexuality, race, and class. Technologies of sex have been used to link the life of the individual to the life of the species as a whole. The management of sexuality was crucial for cultivating (bourgeois) bodies, but also for producing "(internal) enemies" within the body politic. Capable of totalizing and individualizing practices, the biopolitical state became able of exercising authority over the conduct of populations and individuals at every level to "foster" life or "disallow it to the point of death," all in the name of the benefit of its own population.

However, as several authors recognize, the concept of biopolitics is not sufficient for understanding the changes and current logic of global capitalist neoliberal governability. ${ }^{7}$ Foucault's work was not directly theorizing how colonialism is intrinsic to the process of biopower in the past and present. Due to that missing link, as Stoler argues, Foucault's concept of biopolitics fails to define the relationship between technologies of sex and colonial racism, between the notions of sexuality, race and class as fundamental categories of both modern liberal nation-states and global neoliberal capitalist societies. ${ }^{8}$ Racial, sexual and national powers arise not only as a European projection but among colonies and the imperial "home." Mbembe makes the necessary link by adding the concept of necropolitics to conceptualize

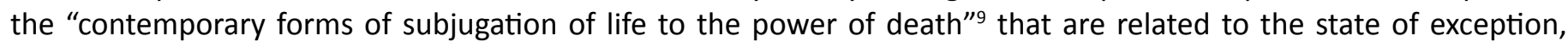
technologies of destruction and war machinery of the global capitalist neoliberal world. Gržinić precisely points out that current logic is rather that of "let live and make die" and that racialization, brutal exploitation, abandonment and the production of "deathscapes" for the production of capital's surplus value are not reserved only for the Second and Third, but are implemented in the First capitalist world as well. As Gržinić demonstrates, neoliberal necrocapitalism thrives on the intensification of its two primal conditions of reproduction, i.e., the privatization and deregulation of society, of all social, political, economic and even artistic practices. Moreover, according to Gržinić, it is possible to argue that today "art and culture, along with theory and criticism and education are pure biopolitical machines (dedicated solely to protecting themselves and their hegemonic Euro-Atlantic interests) while the social and the political (with its allegedly 'autonomous' juridical system) are pure instruments of necropolitical global capitalism."10

\footnotetext{
4 Donald Preziosi, “Art History: Making the Visible Legible," in The Art of Art History: A Critical Anthology (Oxford: Oxford University Press), 1998, 13-18.

5 Jacques Rancière, The Politics of Aesthetics: The Distribution of the Sensible, trans. by Gabriel Rockhill (London and New York: Continuum), 2004.

6 Jonathan Xavier Inda, "Analytics of the Modern: An Introduction", in Anthropologies of Modernity: Foucault, Governementality, and Life

Politics (Oxford: Blackwell Publishing), 2005, 2.

7 See: Achille Mbembe, Marina Gržinić, Ann Laura Stoler.

${ }^{8}$ Ann Laura Stoler, Race and the Education of Desire: Foucault's History of Sexuality and the Colonial Order of Things (London: Duke University Press), 1995.

9 See Mbembe, "Necropolitics," 39.

10 Marina Gržinić, "Biopolitics and Necropolitics in relation to the Lacanian four discourses," Symposium: Art and Research: Shared methodologies. Politics and Translation (Facultad de Bellas Artes de Barcelona), 6-7.9. 2012.
} 
Nevertheless, Foucault's work ${ }^{11}$ is highly important for re-articulating the notion of the archive since it defines the archive as a tool, "the law," which establishes what can be said, transformed and preserved - the systems of discursive practices through the construction of which all traces are produced. What is visible and sayable is also defined by its "dark margin," the unsaid (Agamben). ${ }^{12}$ Although we are aware of the limitation of archival knowledge (of forgetfulness, amnesia, etc.), as Derrida notes, we are burning with a passion for the archive ("en mal d'archive"). ${ }^{13}$ The drive to collect, organize and store human records, to archive, include/exclude, make visible/invisible, is closely related to governmentality and life politics. As both Benjamin and Derrida recognize, the archive - as much as and more than being the question of the past or the archive of the past (the order of memory) - is the question of the present and the promise of the future, and this is where political power lies. Democratisation is measured by "participation in and access to the archive, its constitution, and its interpretation" (Derrida). ${ }^{14}$

Databases are symptomatic of changes in archival power, but we do not have rights not to be digital or to avoid databases today. Besides, the integration of database logic appears, or at least is presented as, inevitable, necessary, playful, self-emancipatory, but also as a response to an emergency requiring the protection of "humans" from "undesirable aliens"/"non humans" (e.g. migration technologies and digital borders aimed at those who would like to become European citizens, or surveillance technologies aimed at depicting possible terrorists) and control over and management of "nature" and "life" itself (e.g. bioinformatics).

As Wendy H. K. Chun indicates, the database, based on memory, encapsulates the logic of programmability ("profilate 'programmed visions', which seek to shape and to predict-indeed to embody-a future based on past data") ${ }^{15}$ and belief in it feeds the current organization of the modern liberal state. Its formulations of freedom and flexibility and its spectres haunt us though our interfaces while we pleasurably create visions that everything is possible. What keeps haunting us in these endless "circuits of drive" are features and fantasies of "communicative capitalism" (fantasies of abundance, participation, unity, wholeness) ${ }^{16}$ which, as Jodi Dean recognizes, continue to produce ambivalent experiences: threats of total control and promises of emancipation, "master/slave" relations and their subversion, or, to use Rancière's terminology, the logic of police and the logic of politics.

Following Foucault's, Deleuze's and Agamben's definitions of apparatuses, I define the database as the major technology of power of global neoliberal governmentality with the capacity to strategically capture, model, control and secure the gestures, behaviours and discourses of living beings, determining what we have been, what we are no longer, and what we are becoming, ${ }^{17}$ thus operating on the intersections of power relations and relations of knowledge.

\section{Body and archive: From flash to human database}

Biopower "made knowledge/power an agent of transformation of human life."18 Knowledge, phantasies and sensations were not produced only in metropoles but in (relation to) colonies, and are crucial for the colonial order of things. This perspective is necessary if we want to understand what knowledge of a "healthy, vigorous, bourgeois body" was all about ${ }^{19}$ and how it created conditions for executing authority over life and death. Why and how is the "citizen" always symbolized by a heterosexual (white) man, while "Western" is read as "global" and "universal"? How are the notion and rights of "real" citizens still maintained through the production of the opposed figure of the "alien" (non-normative sexualities, stigmatized as less "human," "uncivilized," "imported from the East/West," as a threat to the "immunity" of population, to its moral and social order, and as such erased from the citizenship), especially if we bear in mind the promises of databases and networked technologies for destabilizing dominant narratives of racial, sexual and class order?

In addressing the memory politics and sexual regimes of archives/databases, we have to ask how it is that early psychoanalysis appears to have nothing to say about race, although it puts sexuality at the center of its analysis. As Brian Carr demonstrates, the "dark margins" of its archive (racial reality in relation to which the gendered white bourgeois subject is "made"), "protect" it from recognizing the racialized boundary that was produced between

\footnotetext{
${ }^{11}$ Michel Foucault, The Archaeology of Knowledge, trans. A.M. Sheridan Smith (London: Routledge), 2002.

12 Giorgio Agamben, Ono što ostaje od Auschwitza, trans. Mario Kopić (Zagreb: Antibarbarius), 2008.

13 Jacques Derrida, Archive Fever: A Freudian Impression, trans. Eric Prenowitz (Chicago \& London: University of Chicago Press), 1995.

14 Ibid, 4. $\mathrm{n} 1$.

15 Wendy Hui Kyong Chun, Programmed Visions: Software and Memory (Cambridge, MA: MIT Press), 2011, xii.

16 Jodi Dean, Blog Theory: Feedback and Capture in the Circuits of Drive (Cambridge, UK: Polity Press), 2010.

17 Gilles Deleuze, "What is a Dispositif?," in Two Regimes of Madness (New York: Semiotext(e)), 2006, 345.

18 Michel Foucault, History of Sexuality (New York: Vintage Books), 1985, 143.

${ }^{19}$ Stoler, Race and the Education of Desire, 7.
} 
systematic humanization (the human subject's "becoming") and systematic dehumanization (how these subjects are representationaly and symbolically "unmade" - how racialized/colonized "non-subjects" are made). The subaltern is, as Carr argues, a body that is systematically de-signified within a socio-symbolic structure of sexual difference and converted to a dehumanized captive "flash." ${ }^{20}$ It seems that it would be possible to be inscribed as "human" (only) through hegemonic modernist (hetero)narrative.

Furthermore, the emergence of new forms of historical analysis and its discourse helped nations to set up conditions for conceiving social relations in binary terms. ${ }^{21}$ It is a discourse, as Stoler summarizes, whose "truth claims are made to specific rights and by specific holders of them; the rights of a family (to property), of a class (to privilege), of a race (to rule)."22 The technology of sexuality (through which the bourgeoisie would claim its privileged position, absolute rights and jurisdictions as to "how to live"), themes of evolutionism and, above all, racism, would together create conditions to make it acceptable to put certain people to death in order to legitimize bio-regulation, the monstrous idea of "superiority" (of a specific gender, race, class) and "purification" for the sake of normalization. The (re)productive family, and "healthy," "productive" sexuality have been perceived as guaranteeing the welfare of the nation and its citizenry (as morally acceptable and improving of the race), while undisciplined sexuality as a potential threat to both the individual and the population (linking it to natives and "fictive" Europeans). ${ }^{23}$

The affirmation of such a (bourgeois) body, which is worth isolating from others, managing and protecting from numerous dangers through technologies of sex, is a part of the political ordering of life in which human rights are proclaimed universal but applied selectively to those who are perceived as "humans" or good "citizens." Such citizenship has also been gender-coded (women's rights being dependent on their rights of sexual and conjugal contracts with men). The archive's regimes of visibility serve to order and control bodies by inscribing them into and erasing them from humanity and citizenship, granting them and confiscating their civil/human rights.

Such technologies privilege populations over individuals and, in a strange way, as Chun recognizes, even release him/ her from rights and responsibilities. ${ }^{24}$ Monstrous ideas of reproductive control on a large scale - through archives and bio-technologies that focus on sexuality, materialized in movements such as "Eugenics" (Greek: "well born"), which privileged a specific population over the individual, focusing on "death" in order to foster life - did not disappear after showing their real face in Nazi labs, but developed in other forms, using the potential of programmability in socalled democratic societies. Life/death are thus both objects and objectives. In that way, Eugenics and state racism "became ways of giving the state the power of death" (Chun). ${ }^{25}$ Today, killings or deaths are presented as acceptable if a proclaimed "threat to humanity" has been eliminated along with them (e.g., in the war on terror, the immunity of the social body, etc.).

Eugenics and similar bio-technologies, as Chun shows, were not only in charge of high-speed mass calculations at the level of content, but also at the level of "logic or of operationality"26 and optimization, which returns us to the interweaving of computer /database technology and of biology (through memory and programmability), and of the current state of neoliberal capitalism. Chun argues that the drive for an "independent program that conflates legislation with execution - did not arise solely from within computation, but also from early Mendelian genetics and eugenics," 27 which envision a "mechanic understanding of life, in which the human body becomes an archive." 28

In addition to these technologies of life, necropolitics is supported by numerous migratory and death technologies. From centralized databases such as Eurodac (The fingerprint database on EU asylum and illegal border-crossers that enables "digital deportability") $)^{29}$ to drone warfare (capable of identifying and killing the threatening body), different database technologies treat subjects as things deprived of human and citizen rights. There is evident deregulation and lack of attention to any legal boundaries that would regulate the deployment of such surveillance and controlling technologies (issues of privacy, discrimination, principle of limitation, etc.). What is aimed at is standardization of

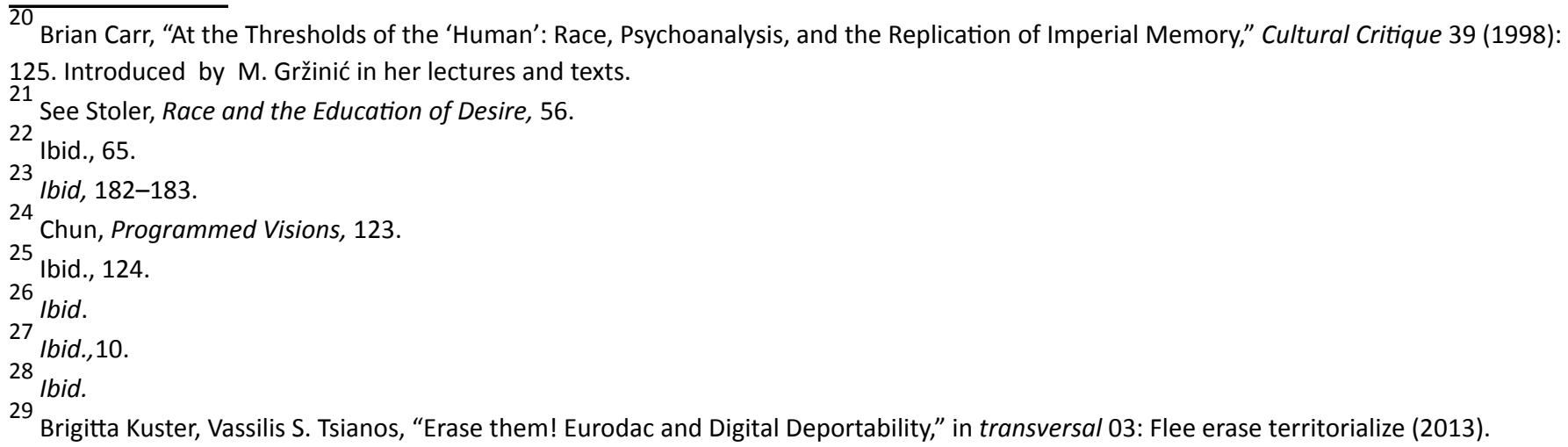


information, usage of all available and collectable data for multiple purposes, centralization and the automation of decision-making. Patterning, profiling a specific type, is increasingly present. These technologies that make bodies legible and establish divisions between citizens and (un)desirable aliens - decisive stigmatizing technologies of inclusion/ exclusion that inscribe archive into the body (though biometric data, DNA, age, voice-testing used for registration) that is dehumanized, excluded from the registration of citizenship, deprived of human rights - are not inventions of the digital age but have been developed from earlier bureaucratic handlings of visual documentation. Allan Sekula showed how photography came to inscribe bodies in the archive, to establish the terrain of the Other, and to define "generalized look-typology" for deviance and social pathology (e.g. Galaton's effort to embed archive in photography, to create a system of typology to control social deviance, or Bertillon's attempt to embed the photo in the archive to create a system of identification and indexing). The effects of such practices are rarely discussed, although concrete political practices and decisions are determined by the knowledge obtained from these programmed memories and databases.

Today, coloniality is digital and none of us has any control of the data or digital traces that are collected about our lives, inscribed into our bodies and exploited for various purposes.

Those to whom rights have not been granted are still used in bioinformatics as a source. Their life is privatized and even commercialized, without informing them of the effects or obtaining their permission for usage (e.g. the Human Genome Diversity Project creating a database of up to 8,000 distinct ethnic populations, even patenting their cell lines). Some Patent Offices granted patents to people who claimed to be able to uncover genetic sequences, which would allow them to use these for commercial purposes for "new products." 30

Apart from predictions concerning the body's disappearance and the hype over online technologies, images of bodies are everywhere (surveilled, scanned, captured, tagged, shared, stored for future visions). The Other is continuously recalled, visualized, but only to be instantly erased from the register of humans and citizens. Non-normative sexuality is strategically visualized in and erased from the register through the image of the undisciplined, racialized and dehumanized Other, never through the image of the good "citizen" (or maybe only through the image of the straight "homonationalist" who reproduces its hierarchical ideals and whom the nation is willing to accept). ${ }^{31}$

Although the internet appears as an "unrestrictive colony" where one might look for experiences "unobtainable" at "home" (virtual cross-dressing, unrestrictive sexualities, etc.), "home" is not far away for "whatever beings" (Jodi Dean), with as Kroker notes, its panic at same-sex marriage, fear of gay desire ${ }^{32}$ and "all the unmourned... violence that is the everyday life experience of women suffering domestic violence and of disappeared sex workers and gays and lesbians." The system of such power, as Kroker notes, is "haunted by paranoiac fears of revenge by those who have been excluded from the spectacle of consumption" ${ }^{33}$ and from the Western ethical order of the "human."

According to Kroker, "body drift" and "sex-code drifters" are today under attack, but are difficult to stop due to the blast of information culture, critical theory such as that of Judith Butler (postmodernism), Katherine N. Hayles (posthumanism), Donna Haraway (companionism), and the artistic practices that envisioned them. ${ }^{34}$

\section{Political and sexual regimes of art histories and the "distribution of the sensible"}

How did it come to be that a standard college text such as H.W. Janson's "History of Art", first written in 1962 (reprinted and sold in more than two million copies), did not include a woman? Such an art history canon seems to welcome only white (upper class) males, omitting everything else that does not fit the official patriarchal hetero-normative (omitting women, but also avoiding treating the homosexual dimension of the life and work of specific "masters"). It produces genders while hiding the fact that it has acknowledged masculinity as universality. As Nanette Salmon notes, it appears that discursive conventions, furnished by Vasari in the $16^{\text {th }}$ century and Janson in the 20th century, promote the heroic male nude and the sexualized, vulnerable female nude (within a framework of the creation of two male-centered

\footnotetext{
30 According to the "Indigenous Peoples Council on Biocolonialism," The U.S. Secretary of Commerce filed a patent claim on the cell line of a 26-year Guaymi woman from Panama in 1996 as if she were a thing. Due to strong protests and criticism, such patents were abandoned. However, some of these cell lines, such as that of a Hangahai man from Papua New Guinea are available to the public at the American Type Culture Collection for \$216 per sample (Source: www.ipcb.org/publications/primers/htmls/ipgg.html).

${ }^{31}$ See Jasbir K. Puar, Terrorist Assemblages: Homonationalism in Queer Times (Duke University Press), 2007, and Jasbir K. Puar, “Mapping US Homonormativities," in Gender, Place and Culture, vol.13., no.1 (2006), 67-88.

32 Arthur Kroker, Body Drift: Butler, Hayles, Haraway (Minneapolis: University of Minnesota Press), 2012, 49.

34 Ibid., 4
} 
desires: homosexual and heterosexual) ${ }^{35}$ and establish power relations among men and women.

The main function of art history is to produce a historical past that is available for systematic observations in the present. As Preziosi notes, its general areas of concern are causality, evidentiality and representativeness. The art objects included are seen as the resultant product of, representative, evidential of age, nation, people, and person. The principal task of all art history and museums has been that of "making the visible legible" in and to the present ${ }^{36}$ (and consequently the future), establishing what is worth seeing and at the same time educating the public in how to read it, "how to activate social memories." Modernity is presented as universal and as an indicator of the civilization of humans. In that way, Preziosi notes, the art of art history came to be "the very esperanto of European hegemony" and "it's ideal horizon and a standard against which to measure all products," including our "exemplary lives." ${ }^{37}$ For every race, class and gender there appears to be "legitimate 'art,", which leads to the conclusion that such "art history makes colonial subjects of us all" (Preziosi). ${ }^{38}$

The invention of aesthetics was supposed to classify a variety of subjects and objects in line with the common axis and on an evolutionary ladder "on whose apex is the aesthetic art of Europe, and whose nadir is the fetish-charm of primitive peoples." ${ }^{39}$ Objects that addressed non-normative sexuality were positioned on the same hierarchical scale. As much as aesthetics was needed for sustaining citizenship and the modern nation-state, fetishism was needed for sustaining the figure of its opposed Other. Neither one of these can be understood in isolation from the other.

Preziosi shows that art history, from its very beginnings and though the triple superimposition that coordinated it (Winckelmann, Kant, Hegel), has been involved in "the fabrication and maintenance of a modernity that linked Europe to an ethically superior aesthetics grounded in eroticized object-relations, thereby allaying the anxieties of cultural relativism, wherein Europe (and Christendom) were, in their expanding encounter with alien cultures, but one reality amongst many." 40

In that sense, rethinking art history requires "forgetting" it or "thinking it otherwise, so as to recollect it more completely." In order to subvert Mastery, we have to critically approach the historical narrative of modernism/postmodernism that is conceptualized within a euro-centric intellectual tradition of exclusion. What is problematic in these notions, as Rancière points out, is that they rely on the idea of historical necessity ${ }^{42}$ and conceptual prejudices, creating a picture of the world in which each individual is granted with an appropriate place and role ${ }^{43}$ (and is seeable and hearable only if they articulate the logic associated with that place). These confusing interrelations and classifications demand not only rejection but a rethinking of the interrelated spheres of art and politics, and of all other objects of thought.

Rancière proposes redefining the concept of aesthetics so as to stand for a kind of "distribution of the sensible" within the Western tradition. In rethinking Rancière's major regimes of identification in Western tradition - the "ethical regime of images," the "representational regime of the arts," and the current ambivalent "aesthetic regime of the arts" 44 (art freed from specific rules, hierarchies of arts, subject-matters and genres)-what is at stake are different "forms of visibility" ("that intervene in the general distribution of ways of doing and making as well as in the relationships they maintain to modes of being and forms of visibility")..$^{45}$

\footnotetext{
${ }^{35}$ Nanette Salmon, "The Art Historical Canon: Sins of Omission," in The Art of Art History: A Critical Anthology, edited by Donald Preziosi (Oxford: Oxford University Press), 1998, 355.

36 Preziosi, "Art History: Making the Visible Legible," 14.

37 Donald Preziosi, "The Art of Art History," in The Art of Art History: A Critical Anthology (Oxford: Oxford University Press), $1998,512$.

38 Ibid, 514.

39 lbid., 514.

40 lbid, 523.

41 lbid., 525.

42 Jacques Rancière in the interview by Sudeep Dasgupta, "Art is Going Elsewhere. And Politics has to Catch It," in Krisis-Journal for contemporary philosophy, no., 1, (2008), 73.

43 Peter Hallward, "Jacques Rancière and the Subversion of Mastery”, in Paragraph: the Journal of the Modern Critical Theory Group, Vol.28 (2005), 26-45.

44 Aesthetic regime allows old forms to coexist with new forms, and is "regime of ambivalence" (Rancière "Art is Going Elsewhere. And Politics has to Catch It," 73)

45 Rancière, The Politics of Aesthetics, 13
} 
Aesthetic experience, as Rancière recognizes, "grounds the autonomy of art, to the extent that it connects it to the hope of 'changing life."' ${ }^{46}$ What defines the aesthetic regime is the binding together of the "autonomy and heteronomy" ${ }^{47}$ of experience which define relations of art and life.

Political potential is not to be found in art itself, in a disturbing element in "a given organization of the relation between the sensible presentation and forms of meaning," which might lead to awareness that there is something wrong with the social order, although this does not mean that such disturbance will lead to some form of mobilization.

If museums were places where the truth of the modern citizen were fabricated and read, who needs these technologies of power today? Even if conditions of visibility change, if databases can bear everything, if anything can be turned into a museum or exhibited, this is mainly because the market can create a surplus value out of it.

The programmability of databases is highly appreciated because it translates political aims into practice. Due to participative technologies and access to databases, we have the illusion of occupying a synoptic position, but from this position it is hard to perceive how liberalism is producing and controlling such illusion.

Participatory art and databases have attracted the strong attention of art institutions since 1989, a period marked by the decline of symbolic efficiency and change in the functioning of the symbolic (Žižek, Dean), de-historicization (Buden, Gržinić), a move from bio-politics to necro-politics (Mbembe, Gržinić), the marketization of art and all other fields, etc. It is also the period of the digitalization and development of "communicative capitalism." This shift, notes Bishop, is parallel to the shift in the story of participation and democracy "from a demand for acknowledgement, to representation, to the consensual consumption of one's own image - be this in a work of art, Facebook, Flickr, or reality TV." But does it mean politics in Rancière's sense, that you speak at the time and in a place you're not expected to speak? It has that potential, but not by default, since in most cases it is just about "standardized democratization" that results in nothing. ${ }^{48}$ The neo-liberal machine promotes such participation (in depoliticizing spaces designed for it) and arrogantly imposes self-responsibility on all forms of lives, while its authorities, who are actually creating algorithms and producing our realities, unresponsively, systematically and strategically destroys them on all possible fronts.

\section{Instead of a conclusion}

An understanding of life in which the human body becomes an archive, read by machines and identified through pattern-recognition algorithms, is the basis of politics that seeks "to rationalize and optimize human populations and capital"(Chun) ${ }^{49}$ Dehumanized data-carriers, racialized things, are translated from humanity into property, upon which the "force of law" and non-application of human rights is treated as acceptable.

The roots of neoliberal governmentality and its sexual regimes are situated in the racist, patriarchal logic of the coloniality of power and its discourses, practices of systematic humanization and dehumanization, and general aims of classification and normalization.

In global neoliberal capital societies, the market is the axis in relation to which every single body, act and human practice have to be positioned. Life is estimated in terms of cost-benefit ("human capital"), and since it is widely propagated that everyone is in control of their own capital (body), "user-friendly" governments rely on the voluntary actions of "well informed" individuals. Technologies, such as databases, appear to follow a similar logic and equalize standardized and participatory practice within a designed framework as emancipation and democracy par excellence. As Chun points out, "the dream is: the resurgence of the seemingly sovereign individual, the subject driven to know, driven to map, to zoom in and out, to manipulate, to act," ${ }^{50}$ while at the same time $\mathrm{s} /$ he is tracked, controlled, privatized, exploited, abandoned. Databases, as memory machines, activate such dreams (and nightmares) - based on past data, they offer a promise of a calculable future..$^{51}$

The current state of neoliberalism engenders the Other in the body that resists the normativity of cost-effectiveness. This is how some life decisions are acceptable (transnational child adoption), LGBT integration into consumerism rights

\footnotetext{
$\overline{46}$ Jacques Rancière, "The Aesthetic Revolutions and Its Outcomes: Emplotments of Autonomy and Heteronomy," New Left Review, no.14, (2002),134.

47 Ibid.

48 lbid.

${ }^{49}$ Chun, Programmed Visions, 98

50 Ibid., 8.

51 lbid.
} 
(market' diversity, tourism, creative industries, advertisements, etc.) and "standardized democratic spheres" desirables (homonationalism), visibility instrumentalized ("pinkwashing" strategies to divert attention from denial of rights on other fronts ${ }^{52}$ ), while full inclusion in citizenship is still denied and gender-based violence and racism is tolerated.

The programmability of databases makes the database a powerful technology of power, of distinction, transformable discourses, and control. Escape from it appears unimaginable, inconceivable, unrepresentable. However, that is the apparatus's strategic task. Lines of cracking are also one of its specificities, and cuts of its vicious circle might help us to try imagining the possibilities of resistance and of new subjectivities.

Theoretical and artistic practices have often been assigned with such promises, or even a role to resist and subvert norms and Mastery. Such resistance does not mean a break with the past, but rather a call for the de-classification and de-normalization of all these overlapping spaces and critical analysis of the performativity of epistemological practices in order to understand the promises they set for producing the past, present and future, as well as the roles and positions that have been assigned to us.

Adla Isanović is an Assistant Professor at The Academy of Fine Arts, Sarajevo, in courses on Multimedia. She holds an MA in "Critical, Curatorial, Cybermedia Studies" (Ecole supérieure des beaux arts), and an MA in "New Media" (Haute Ecole d'arts appliqués), Geneva, Switzerland. Her previous engagements include work as a researcher/analyst at The Mediacentar Sarajevo, a visiting lecturer at The International University, Sarajevo, and The Academy of Performing Arts, Sarajevo, and involvement in local and international projects in the fields of media research, culture and art.

\section{Bibliography:}

Agamben, Giorgio. 2008. Ono što ostaje od Auschwitza. Translated by Mario Kopić. Zagreb: Antibarbarius.

Agamben, Giorgio. 2009. What is an Apparatus: and Other Essays. Stanford: Stanford University Press.

Carr, Brian.1998 "At the Thresholds of the 'Human': Race, Psychoanalysis, and the Replication of Imperial Memory." Cultural Critique 39.

Chun, Wendy Hui Kyong.2011. Programmed Visions: Software and Memory. Cambridge, MA: The MITPress.

Dean, Jodi. 2010. Blog Theory: Feedback and Capture in the Circuits of Drive. Cambridge, UK: Polity Press.

Deleuze, Gilles. 2006. "What is a Dispositif?", in Two Regimes of Madness. 338-348. New York: Semiotext(e).

Derrida, Jacques. 1996. Archive Fever: A Freudian Impression. Chicago: The University of Chicago Press.

Foucault, Michel. 1985. History of Sexuality. New York: Vintage Books.

Foucault, Michel. 2002. The Archaeology of Knowledge. Translated by A.M. Sheridan Smith. London: Routledge.

Gržinić, Marina.2010. "From Biopolitics to Necropolitics and the Institution of Contemporary Art." In Pavilion No 14, "Biopolitics, Necropolitics and De-coloniality", guest editor M. Gržinić.9-93.

Gržinić, Marina. 2012. "Biopolitics and Necropolitics in relation to the Lacanian four discourses", Simposium: Art and Research: Shared methodologies. Politics and Translation. Facultad de Bellas Artes de Barcelona.

Hallward, Peter. 2005. "Jacques Rancière and the Subversion of Mastery." In Paragraph: the Journal of the Modern Critical Theory Group, Vol. 28. 26-45.

52 Jasbir K. Puar, "Israel's gay propaganda war," in The Guardian, 1 July 2010 (Puar argues that Israel uses a PR strategy described as "pinkwashing," equating Israel's internal policies toward gays with modernity, progressive democracy, and tolerance, as an attempt to divert due attention from campaigns of aggression against Palestinians, www.guardian.co.uk/commentisfree/2010/jul/01/israels-gay-propaganda$\underline{\text { war) }}$ 
Inda, Jonathan Xavier (ed.). 2005. Anthropologies of Modernity: Foucault, Governmentality, and Life Politics. Oxford: Blackwell Publishing.

Kroker, Arthur. 2012. Body Drift: Butler, Hayles, Haraway. Minneapolis: University of Minnesota Press.

Kuster, Brigitta, Vassilis S. Tsianos. 2013. "Erase them! Eurodac and Digital Deportability." Translated by Erika Doucette \& Sam Osborn, in transversal 03: Flee erase territorialize. http://eipcp.net/transversal/0313/kuster-tsianos/en

Manovich, Lev. 2007. "Database as Symbolic Form." In Database Aesthetics: Art in the Age of Information Overflow. Edited by Victoria Vesna. 39-61. Minneapolis: University of Minnesota Press.

Mbembe, Achille. 2003. “Necropolitics.” Translated by Libby Meintjes. Public Culture 15/1. 11-40.

Preziosi, Donald. 1998. "Art History: Making the Visible Legible." In The Art of Art History: A Critical Anthology, 13-18. Oxford: Oxford University Press.

Preziosi, Donald. 1998. "The Art of Art History." In The Art of Art History: A Critical Anthology, 507-525. Oxford: Oxford University Press.

Puar, Jasbir K. 2005. “Queer Times, Queer Assemblages.” In Social Text, Vol. 23, no. 3-4.121-140.

Puar, Jasbir K. 2006. "Mapping US Homonormativities." In Gender, Place and Culture: A Journal of Feminist Geography, vol. 13, no.1. 67-88.

Puar, Jasbir K. 2007. Terrorist Assemblages: Homonationalism in Queer Times. Duke University Press.

Rancière, Jacques. 2002. "The Aesthetic Revolutions and Its Outcomes: Emplotments of Autonomy and Heteronomy." New Left Review. No 14. 133-151.

Rancière, Jacques. 2004. The Politics of Aesthetics: The Distribution of the Sensible. Translated by Gabriel Rockhill. London \& New York: Continuum.

Rancière, Jacques. 2008. "Art is Going Elsewhere. And Politics has to Catch It." Interview by Sudeep Dasgupta. In Krisis-Journal for Contemporary Philosophy, No.1.70-76.

Salmon, Nanette. 1998. "The Art Historical Canon: Sins of Omission" in The Art of Art History. Edited by Donald Preziosi. 344-355. Oxford: Oxford University Press.

Stoler, Ann Laura. 1995. Race and the Education of Desire: Foucault's History of Sexuality and the Colonial Order of Things. London: Duke University Press.

Stoler, Ann Laura. 2002. "Colonial Archives and the Arts of Governance." Archival Science 2, no.1-2. 87-109. 